\title{
FLUID STATE OF ARCHITECTURE
}

\section{Bojana Jerković-Babović}

University of Belgrade - Faculty of Architecture

bojana.jerkovic@arh.bg.ac.rs

\section{A B S S T R A C T}

This paper focuses on the changes in architectural aesthetic criteria, from static to dynamic values of both figurative and non-figurative aspects in contemporary architecture and its cultural context. Fluid state of architecture refers to the notions of constant variability occurring in relations between architecture and contemporary cultural context of globalisation. Contemporary context dynamises everyday perceptual experiences, living conditions and terms of spatial appropriations. Accordingly, new networking phenomena appearing on informational, communicational and spatial levels transform the city and architecture into constant process of flows, dematerialising its elements into the new fluid, variable character. Architectural aesthetic qualities simultaneously shift trough events and effects affirmation over static formal whole in transformation from objective to (inter)subjective aesthetic spatial experience.

This paper is based on hypothesis that contemporary architecture is characterised by the loss of object singularity in terms of contextual conditions and assimilation of particular characters into the dynamic character of the whole. Therefore, architectural design principles shift through dispersion of disciplinary boundaries and boundaries of inner and outer architectural space, hybridity and typological definition loss. This paper presents how dematerialisation of architectural values transforms contemporary architectural space into the complex dynamic system of infrastructure, flows, events and effects. 


\section{INTRODUCTION}

This paper researches the concept of fluid state of architecture based on its relations with the contemporary cultural, socio-spatial context. Additionally, fluid state of architecture refers to the notions of constant variability occurring as a result of contemporary everyday experience dynamisation, living conditions and spatial appropriations in the post-postmodern context of globalisation and informational revolution. Therefore, this paper focuses on the changes in architectural aesthetic criteria shifting from static to dynamic values of both figurative and non-figurative aspects of contemporary architecture. This paper aims to present the potentials of design principles in produced state relying on aesthetic reading of spaces of flows and dynamisms in architecture of contemporary living. The new cultural phenomena resulting in global technological, political and economic changes are creating the potentials of the new meanings and new aesthetic reading in architecture. Therefore, the dynamic concept of flows is positioned into the spatial perspective as architectural design criteria in response to dematerialisation of architectural aesthetical object and perceptual effects overproduction.

\section{Fluidity of Contemporary Context of Architecture}

Contemporary, dynamic context of global networks and consumerism is characterised by constant processes of exchange and changes of material basis of everydayness. Fluid, variable, intense processes of population mobility, information exchange and communicational interactions change contemporary cultural and aesthetic experience. Therefore, dynamic experiences reflect on the perception and spatial experience of architecture and the city. In this paper, fluidity is positioned as the main contemporary conceptual phenomenon, simultaneously causing and manifesting in contemporary transformations of social and spatial conditions into a constant process of interacting flows. In addition, contemporary networked context is characterised by increasing effects of globalisation, such as transnational, transcultural exchanges and constant flows of money, goods, people, tourists, migrants, information, ideas, etc. Transfer and transport networks become the communicative devices of modern life. ${ }^{1}$ Therefore, (post)postmodern socio-spatial context transformed notions of mobility into the new aspects, manifested in dynamic, flowing, variable and constantly changing experiences of everydayness - aspects of fluidity. 
Contemporary networking phenomena transform the urban context into the processes of constant flows and dynamics, dematerialising its structural elements into the new fluid, liquid and flowing character. Increasing technological development accelerates the everyday life, where functions of the society are based on the phenomenon of flows - 'flows of capital, flows of information, flows of technology, flows of organisational interaction, flows of images, flows of sounds and symbol,' according to Manuel Castells. ${ }^{2}$ In addition, Castells says: 'Flows are not just one element of the social organisation: they are the expression of processes dominating our economic, political and symbolic life'. ${ }^{3}$ In addition, Castells says that 'global city is not a place, it is a process' and 'the emphasis on interactivity between places breaks up spatial patterns of behaviour into a fluid network of exchanges that underlines the emergence of a new kind of space - space of flows'. ${ }^{4}$

This research is based on the reading of the new sense of perceptively, sensory and experiential values of the contemporary conditions occurring in relation between architecture and its context. Therefore, the notion of flow becomes the element of fluidity manifested in sensory complexity and perception of constant movement and dynamics. In addition, fluidity is considered as new aesthetical quality based on constant perceptual sequences change and dynamic formal implications in architectural and urban space.

\section{FLUID STATE OF ARCHITECTURE}

According to the presented conditions of the contemporary context, the position of architecture manifests in the transformation of values and material basis of our contemporary everyday experiences.

Castells' opinion, poststructuralist itself, puts the ideas of difference and repetition in the thinking of urban structure, as constants of spatial transformation into the dynamic process. Accordingly, flows articulation in the spatial perspective becomes a query of architectural and cultural relation - a relation between formal representations and new cultural and social meanings. Accordingly, subjectivity affirmation, variability and structural dynamisation of architectural space occur as the opposites to the historic fundaments of architectural form and its aesthetics. The notion of flow, as kinesthetic and relational criteria, becomes the constitutive of formal spatial qualities. In addition, programmatic hybridity and typological definition loss manifest the dispersion of old and affirmation of new architectural design principles. 
From Artefacts to Effects -

Non-Figurative Aspects of Fluidity in Architecture

In the analyses of cultural and architectural discourse terminology changes after 1960s, the phenomenon of flows becomes increasingly present in postmodern cultural transformations, in the words of Zygmunt Bauman - "fluid life", "liquid love", "liquid fear", "liquid modernity", etc. ${ }^{5}$ The aesthetic experience of contemporary life, the city, architecture and art becomes 'scattered in the gaseous state', according to the philosopher Yves Michaud. ${ }^{6}$ In addition, Michaud says that absolute "aesthetic triumph" transforms the aesthetic experience into the experience of everydayness. ${ }^{7}$ In order to meet existential, consumer, touristic and hedonistic needs of neoliberal capitalist society, the transit of aesthetic experience into the fluid state is a result of the pleasure occurring during the experience that is flowing, autonomous, intuitive and easy to understand. ${ }^{8}$

Psychologist Mihály Csíkszentmihályi names the pleasant experience, the one requiring undistracted, continuous attention and perception, the "flow experience". ${ }^{9}$ Kinesthetic experience principle in architecture is the most dominant one in phenomenological and poststructuralist thoughts of spatial perception and relation between subject and its physical context. In addition, kinesthetic as a spatial understanding by movement occupies subject attention creating Csíkszentmihályi`s "flow experience", which is fluid, autonomous, subjective and pleasant.

The relation between kinesthetic, perception and subject-space interaction could be recognised in the affective dimension of perception in philosophical discourse of Henri Bergson and phenomenological elaboration of perception by Maurice Merleau-Ponty and theory of perception by Mark Hansen. ${ }^{10}$ Action and involving the body in the visual field is a precondition of perception and each sensory sensation, according to Hansen..$^{11}$ Additionally, Hansen emphasises the central role of the body in cognitive process of perception in which visual image is created by the action of the body in space in which perception is homogenised with space.

Therefore, the relation between visual, nonmaterial and material in the process of creating the perceptual experience is formed. Additionally, process of conceptualisation allows logical systematisations of perception, subjectivity and intuitive experiences of space. Subjectivity, as opposed to historically fundaments of meaning and style in architectural form, becomes the main potential of contemporary dynamic context. Reduction of historical formal 
rhetoric and technological transformation of creative, design tools in architecture reshaped the non-figurative aspects of architectural aesthetics into the fluid, variable qualities. Therefore, architectural aesthetic qualities are shifting towards dynamic events and effects affirmation over static formal whole, transforming from objective to (inter) subjective aesthetic spatial experience.

The Position of a Form in a Process Figurative Aspects of Fluidity in Architecture

The notion of flow in urban context is explained by Manuel Gausa as an internal interior of no defined boundaries, where users are located in the form of flow. ${ }^{12}$ Bernard Tschumi says that architecture is "the form of flow" consisted of sequences of events, activities and movement occurring within static architectural elements. ${ }^{13}$ In addition, the book Architecture and Disjunction refers to the idea that there is no architecture without programme emphasising that social relevance and formal invention could not be separated from the events within. Accordingly, architecture is simultaneously produced, reproduced, designed and experienced. Tschumi's sequences of programme present assemblages of events stringed along assemblages of spaces, where each cadre changes, marks, increases the ones that follow. Therefore, Tschumi's theory affirms plurality of interpretations rather than individuality and the idea that each spatial part is simultaneously complete and incomplete and non-determent. ${ }^{14}$

Poststructuralist philosophy influence on architectural theory is notable in a change of terminology and the use of notions such as flow, flux, dynamism, etc. expressing the values change and architecture becomes the synthesis of temporal-spatial elements, movement and variability. Gausa says that 'advanced architecture is the architecture of flows and exchanges between local and global, individual and culture, place and city, information, technology and behavior, time and context' ${ }^{15}$

In the book Differences, Ignaci de Solaa Morales Rubiao researches the relation between architecture and its context, which is characterised by the absence of clear value system legitimised and widely accepted to be the basis for the design practice. ${ }^{16}$ Additionally, Solaa Morales researches the phenomenon of aesthetic values dispersion and absence of fundamental referents in contemporary architecture, in the relation between poststructuralist philosophy and architecture. ${ }^{17}$ 
Therefore, postmodernism appears to be the manifestation of poststructuralist thoughts on difference and repetition, suggesting the queries of subjectivity and architectural presentation. Accordingly, subjectivity occurs as the opposite to historical fundaments and style characteristics in architectural form. According to Solaa Morales, the architect invokes the individual memory of the users in space. ${ }^{18}$ In addition, architectural form is characterised by the generic principles which reduce historical formal rhetoric, symbols and meanings leading towards formal abstraction and shifting users' focus and perception to gestures, flows, movements and events. Architecture becomes more direct to observe and use, more temporal and individually understood.

Additionally, contemporary architecture design principles are characterised by the dispersion of disciplinary boundaries and boundaries of inner and outer architectural space. Therefore, figurative aspects of architectural aesthetic changes reflect in hybridity of programmes and forms resulting in typological definition loss. Architectural formal and functional criteria is based on articulation, affirmation and adjustment to the flows, dynamics and events occurring both in architecture and its context. Such architectural queries are results not just of technological shifts, but also of the new meanings and values. Contemporary architectural criteria are positioned in the process of shaping the perception of architectural and urban space, creating the relation between individual and society. Therefore, non-figurative and figurative aspects of architecture simultaneously reflect in transformations of architectural form and its meanings. Transformations of architectural form and hybrid structures result in more often disciplinary intersections and transgressions. Rem Koolhaas, Stan Allen, Martin Pawley, Keller Easterling, etc., research needs and possibilities of architecture-infrastructure-landscape unification into one dynamic spatial system. ${ }^{19}$

Therefore, transdisciplinary transformations overlap architecture and infrastructure with landscapes, both natural and urban, creating the poststructuralist Deleuzian space with softened boundaries, based on fluid qualities and continuity.

\section{CONCLUSION}

The aim of this paper was to research the hypothesis that contemporary architecture is characterised by the loss of object singularity in terms of contextual conditions and assimilation of particular characters into the dynamic 
character of the unique system. The main idea presented in this paper is based on the dematerialisation of architectural aesthetic values and transformations of architectural space perception based on the complex dynamic systems of infrastructure, flows, events and effects. Therefore, such changes appear as expressions of architectural historical fundaments dispersion, fading and even negation. Disciplinary overlaps, intersections and transgressions create new design principals and potentials and new aesthetic readings.

Accordingly, the dynamic concept of fluidity is positioned into the spatial perspective as contemporary architectural state appearing in response to dematerialisation of architectural aesthetical object and perceptual effects overproduction, the loss of spatial boundaries between inner and outer space, hybridity, typological definition loss and the continuity of constant changes. 

in Serbia in the context of globalization and European integrations for the purpose of improving housing quality and standards" (TR36034), financed by the Ministry of Education and Science of the Republic of Serbia.

Manuel Castells, The Rise of The Networked Society, With a New Preface: Volume I: The Information Age: Economy, Society and Culture (London: John Willey and Sons, 2009). 1996), 442.

Manuel Castells, The Rise Of The Networked Socitety, 2. ed. (Oxford: Blackwell Publishers, 1996), 442 .

Manuel Castells, The Rise Of The Networked Socitety, 2. ed. (Oxford: Blackwell Publishers, 1996), 417,429 . Liquid Life (Cambridge, UK: Polity Press, 2005).

Yves Michaud, Umjetnost u plinovitu stanju, trans. Jagoda Milinković and Žarko Paić (Zagreb: Naklada Ljevak, 2004) 
Yves Michaud, Umjetnost u plinovitu stanju, trans. Jagoda Milinković and Žarko Paić (Zagreb: Naklada Ljevak, 2004).

Yves Michaud, Umjetnost u plinovitu stanju, trans. Jagoda Milinković and Žarko Paić (Zagreb: Naklada Ljevak, 2004).

Mihaly Csiksentmihailyi, Flow: The Psychology of Optimal Experience (New York: Harper and Row, 1990).

Mourice Merleau-Ponty, Phenomenology of perception (London: Routledge, 2002), Mark Hansen, New philosophy for new media (Cambridge, Mass.: MIT Press, 2004), 252.

Manuel Gausa, Willy Muller, Vicente Guallart, The Metapolis Dictionary of Advanced Architecture: City, Technology and Society in the Information Age (Barcelona: Actar, 2003), 309.

Manuel Gausa, Willy Muller, Vicente Guallart, The Metapolis Dictionary of Advanced Architecture: City, Technology and Society in the Information Age (Barcelona: Actar, 2003), 309. 1999); Martin Pawley, Terminal Architecture (London: Reaktion Books, 1998). 
Allen, Stan. Points + Lines. New York: Princeton Architectural Press, 1999.

Bauman, Zygmunt. Liquid Modernity. Cambridge, UK: Polity Press, 2000.

Bauman, Zygmunt. Liquid Life. Cambridge, UK: Polity Press, 2005.

Castells, Manuel. The Rise of the Networked Society, With a New Preface: Volume I: The Information Age: Economy, Society and Culture. London: John Willey and Sons, 2009.

Castells, Manuel. The Rise of the Networked Society 2. ed. Oxford: Blackwell Publishers,1996.

Csiksentmihailyi, Mihaly. Flow: The Psychology of Optimal Experience. New York: Harper and Row, 1990.

De Solà-Morales Rubió, Ignasi and Sarah Whiting, Differences. Cambridge: The MIT Press, 1997. Easterling, Keller. Organization Space. Cambridge, Mass.: MIT Press, 1999.

Gausa, Manuel and Willy Muller, Vicente Guallart. The Metapolis Dictionary of Advanced Architecture: City, Technology and Society in the Information Age. Barcelona: Actar, 2003.

Hansen, Mark. New philosophy for new media. Cambridge, Mass.: MIT Press, 2004.

Koolhaas, Rem and Bruce Mau, Jennifer Sigler, Hans Werlemann. Small, Medium, Large, ExtraLarge. New York: Monacelli Press, 1998.

Michaud, Yves. Umjetnost u plinovitu stanju, trans. Jagoda Milinković and Žarko Paić. Zagreb: Naklada Ljevak, 2004.

Merleau-Ponty, Mourice. Phenomenology of perception. London: Routledge, 2002.

Tschumi, Bernard. Arhitektura i disjunkcija, trans. Silva Kalčić. Zagreb: AGM, 2004.

Pawley, Martin. Terminal Architecture. London: Reaktion Books, 1998. 


\section{ESTETIKA ODRŽIVOSTI: ARHITEKTURA KAPSULE U GRADU I U PRIRODI Peter Šenk}

Arhitektura najmanjih mesta za stanovanje je u poslednje vreme izuzetno popularna tema. Kada su najmanja mesta za stanovanje kompaktna, dobro opremljena, povezana na mrežu, strukturno, funkcionalno i vizuelno prepoznata kao jedna stvar, privremena i pokretna ili prenosiva, mogu se označiti kao arhitektura kapsule. Budući da su po svojoj prirodi privremena, ova najmanja mesta za stanovanje, skloništa, redizajnirane kontejnerske jedinice, posebne tehnološke konstrukcije, paraziti i druge manifestacije koncepta kapsula obuhvataju logiku tehnoloških objekata s izrazitim arhitektonskim izrazom. To je, istovremeno, manifestacija pravila održivog dizajna, održive arhitekture i održivosti uopšte. U ovom kontekstu slučaj najmanjih mesta za stanovanje pokazuje svoju razliku u odnosu na druge održive arhitektonske pristupe i estetike. Podredjuje uopšteno održive pristupe sa izraženim značajem lokaliteta unutar globalnih sila, obično se oslanjajući na kontekst - lokaciju, lokalnu kulturu i karakteristike životne sredine itd. Estetski režim trenutnih, promenljivih, kontekstualnih i autonomnih arhitektonskih struktura se može posmatrati kao estetika drugosti, koja ih povezuje sa nasledjem egzistencijalnih eksperimenata modernog pokreta, novim brutalizmom, radikalnim eksperimentima 1960-ih i drugim avangardnim i neoavangardnim praksama dvadesetog veka, ali čvrsto postavljenim u kontekstu individualizovane, neodredjene, raspršene i dvosmislene savremenosti.

KLJUČNE REČI: ESTETIKA PROMENE, KAPSULE, NAJMANJA MESTA ZA STANOVANJE, MINIMALAN TRAG, DRUGOST, ESTETIKA ODRŽIVOSTI

\section{ESTETIKA I KULTUROLOŠKI ASPEKTI BAUHAUSA: \\ KA NOVOJ KONCEPCIJI}

\section{Christiane Wagner}

Ovaj članak pokriva nove mogućnosti Bauhaus pogleda na svet: stvaranje novih oblika za prikazivanje ljudskih ideala kroz fokus na estetiku i tehnologiju, u kombinaciji sa Nimajerovim (Niemeyer) uticajem na arhitekturu i dizajn. Novi stilovi i oblici nastali su kao izdanci Bauhausa, prenoseći vrednosti svake kulture kroz izgradnju kolektivne „slike“ sveta. Bauhaus današnjice izražava industriju kulture, dijalektički razmatrajući inovaciju i primenjenu umetnost kao put od modernog dizajna industrijske revolucije do „eko dizajna“. U tom smislu, Bauhaus je još uvek značajan po svojoj ulozi, povezujući umetnost, tehnologiju i industriju. Inovacija kao dinamično odredjivanje trenutka, prisutna u svim epohama, se shvata kao moćna sila za održavanje tradicije. Pored hronološkog zapisa o uticaju Bauhausa, razmatraju se i značajni Nimajerovi projekti. Na kraju su prikazane dve perspektive ,raskola“ izmedju arhitekture i tehnologije. Prva perspektiva se odnosi na ljudsku sposobnost stvaranja modela u arhitektonskoj praksi za usvajanje kao konfiguraciju prostora. Druga se odnosi na evoluciju tehnologija koje vode do toga da zamišljeno postaje stvarnost kroz vreme, kako je to opisao Hegel (1823).

KLJUČNE REČI: IZRADA PO MERI, TEHNOLOŠKI RAZVOJ, PROSTOR-VREME, NOVI OBLICI

\section{KLASIČNA ARHITEKTURA U OKVIRU KANTOVSKE ESTETIKE: IZMEĐU LIOTARA I RANSIJERA}

\section{Helen Tatla}

Potencijal koji je svojstven klasičnoj arhitekturi da predstavlja glavni arhitektonski izraz zapadne kulture budući da je grčka antika nastala zbog svog dualnog karaktera: iako izvire iz iskonskog jedinstva stvari izraženih mitom i religijom u arhaičnim vremenima, ona dobija svoj završni oblik u petom veku p. n. e., kao simbol demokratije i harmonične artikulacije sveta na osnovu filozofskog mišljenja. 
Postavljajući avangardnu umetnost u sferu kantovske uzvišenosti, Žan Fransoa Liotar (JeanFrancois Lyotard) se fokusira na nemogućnost apsolutnog odnosa razuma i percepcije ili između razmišljanja i slike, u savremenosti. On smatra da se u slučajevima kada se to dogodi radjaju politička čudovišta. On povezuje postmoderne izraze klasicizma u arhitekturi sa Frojdovim „Tumačenjem snova“" i kantovskom lepotom.

Pristup Žaka Ransijera (Jacques Ranciere) kantovstvu na osnovu estetskog razmatranja modernosti suprotan je onome koji je predložio Liotar. Umesto uzvišenog, Ransijer povezuje lepo s pukotinom izmedju razmišljanja i percepcije. U tom pogledu, fragmenti prošlosti mogu da podstaknu kreativni proces u sadašnjosti.

Cilj ovog istraživanja je da doprinese dijalogu o obnovljenom pristupu ulozi klasicizma u arhitekturi danas.

KLJUČNE REČI: KLASIČNA ARHITEKTURA, KANT, LIOTAR, MODERNOST, POLITIKA, POSTMODERNOST, RANSIJER

\section{FLUIDNO STANJE ARHITEKTURE}

\section{Bojana Jerković-Babović}

Ovaj rad se bavi promenama u kriterijumima arhitektonske estetike, transformacija statičnih u dinamične vrednosti podjednako figurativnih i nefigurativnih aspekata savremene arhitekture i njenog konteksta. Fluidno stanje arhitekture odnosi se na prepoznavanje konstantne promenljivosti koja se manifestuje u relacijama arhitekture i savremenom kultuloroškog konteksta globalizacije. Savremeni kontekst dinamizuje perceptivna iskustva svakodnevnice, uslove života i načine prostornih aproprijacija. U skladu sa tim, novi fenomeni umreženosti koji se manifestuju na informacionim, komunikacionim i prostornim nivoima transformišu grad i arhitekturu u konstantne procese tokova, kojima se njihovi elementi dematerijalizuju u nove fluidne, promenljive karakteristike. Vredosti arhitektonske estetike istovremeno se transformišu ka afirmaciji dogadjaja i efekata naspram statične formale celine, od objektivnih do intersubjektivnih estetskih prostornih iskustava.

Ovaj rad se bazira na hipotezi da savremenu arhitekturu karakteriše gubitak singularnosti objekta u odnosu sa uslovima konteksta i asimilacija karaktera pojedinačnih elemenata u fluidni karakter celine. Na taj način, arhitektonske projektantske principe karakteriše disperzija disciplinarnih granica i granica unutrašnjosti i spoljašnjosti, hibridnost i gubitak tipoloških definicija. Ovaj rad prikazuje kako dematerijalizacija arhitektonskih vrednosti transformiše savremeni arhitektonski prostor u kompleksan dinamički sistem infrastrukture, tokova, događaja i efekata.

KLJUČNE REČI: ARHITEKTONSKA ESTETIKA, ARHITEKTONSKO PROJEKTOVANJE, ESTETSKO ISKUSTVO, DINAMIČKE VREDNOSTI, FLUIDNOST, GLOBALIZACIJA

\section{KINEMATOGRAFIJA I ARHITEKTURA: MODERNA PERCEPCIJA Sônia Campaner Miguel Ferrari}

Esej Valtera Benjamina (Walter Benjamin) o bioskopu objašnjava njegove prognostičke vrednosti. Dok je pisao ovaj članak, njegova kritika kapitalističkog načina produkcije pokazala je pravac u kojem kapitalizam napreduje: ka sve većoj eksploataciji proletarijata, ali i ka svom vlastitom padu. Nas zanimaju ove prognoze koje potvrdjuju transformaciju umetnosti i njene funkcije, a koja našu pažnju usmeravaju na gubitak transcedencije i opadanja aure umetničkog dela. One u isto vreme pokazuju mogućnosti kojima se potvrđuje kontinuitet umetnosti koja ima drugačiju ulogu i dislokacija aure. Oblik umetnosti koji je pogodan za ovakvo razmišljanje je kinematografija i paralela koju je filozof povukao izmedju kinematografije i arhitekture. Namera nam je da se osvrnemo na ovu paralelu i urbane intervencije kao umetničke oblike estetske modernosti: to 